\title{
Proteins from Tuber magnatum Pico fruiting bodies naturally grown in different areas of Italy
}

\author{
Federico Vita ${ }^{1}$, Valentina Lucarotti ${ }^{1}$, Emanuele Alpi ${ }^{2}$, Raffaella Balestrini ${ }^{4}$, Antonietta Mello ${ }^{4}$, Angela Bachi ${ }^{2}$,
} Massimo Alessio ${ }^{3}$ and Amedeo Alpi ${ }^{1 *}$

\begin{abstract}
Background: A number of Tuber species are ecologically important. The fruiting bodies of some of these also have value as a cooking ingredient due to the fact that they possess exceptional flavor and aromatic properties. In particular, T. magnatum fruiting bodies (commonly known as truffles), are greatly appreciated by consumers. These grow naturally in some parts of Italy. However, the quality of these fruiting bodies varies significantly depending on the area of origin due to differences in environmental growth conditions. It is therefore useful to be able to characterize them. A suitable method to reach this goal is to identify proteins which occur in the fruiting bodies that are specific to each area of origin. In this work protein profiles are described for samples coming from different areas and collected in two successive years. To our knowledge this is the first time that proteins of T. magnatum have been thoroughly examined.

Results: Using two dimensional electrophoresis, reproducible quantitative differences in the protein patterns (total 600 spots) of samples from different parts of Italy (accession areas) were revealed by bioinformatic analysis. 60 spots were chosen for further analysis, out of which 17 could probably be used to distinguish a sample grown in one area from a sample grown in another area. Mass spectrometry (MS) protein analysis of these seventeen spots allowed the identification of 17 proteins of T. magnatum.
\end{abstract}

Conclusions: The results indicate that proteomic analysis is a suitable method for characterizing those differences occurring in samples and induced by the different environmental conditions present in the various Italian areas where T. magnatum can grow. The positive protein identification by MS analysis has proved that this method can be applied with success even in a species whose genome, at the moment, has not been sequenced.

Keywords: Tuber magnatum, Proteins, Fruiting bodies, 2D-electrophoresis, Mass spectrometry, qPCR

\section{Background}

The ectomycorrhizal fungus Tuber magnatum Pico is an hypogeous ascomycete that forms specialized symbioses with fine roots of higher plants. The interest on this specific Tuber is undoubtedly related to its ecological role in boreal and temperate forests, though the use of its fruiting bodies (commonly known as truffles) as a cooking ingredient is certainly equally relevant. Truffles are greatly appreciated for their intense flavor and aroma. [1]. Several attempts have been made to artificially grow this fungus, which to date have been unsuccessful. As a result, the fruiting bodies must be obtained from their

\footnotetext{
*Correspondence: aalpi@agr.unipi.it

'Department of Crop Plant Biology, University of Pisa, via Mariscoglio 34, 56124 Pisa, Italy

Full list of author information is available at the end of the article
}

natural place of growth, in the woods. Knowing where to look for truffles requires years of training and experience, and often requires the help of specially trained animals, for example dogs. In addition, the fruiting bodies grow only in a restricted number of locations and environments. These difficulties, together with the high demand for truffles on the market, drive up their price significantly.

The quality of the fruiting bodies can be affected by their place of origin. A reliable method to differentiate between truffles from different locations - and thus reassure to consumers as to the quality of the product they will pay a high price for - has long been sought.

T. magnatum is present in some parts of Italy (Tuscany, Piedmont, Marche, Umbria, etc.), Istria and in several Balkan regions. The quality of its fruiting bodies is variable 
and depends on the environment and the growth conditions. Due to limited availability and high market value, T. magnatum is the subject to fraudulent claims [2]. Gene expression, and consequently the protein profile, is strongly influenced by many factors. In addition to the conditions in the location where the fungus grows, these include the developmental stage of the fungus itself, and small genetic variations. This last factor has been recently shown to correlate with variability in volatile compound production in T. aestivum [3].

The life cycle of a truffle can be divided into stages [4] and many attempts have been made to characterize and to distinguish them in species that are very similar from a morphological point of view (e.g., white truffles group). To reach this goal conventional classification methods have been used, as well as more sophisticated analytical tools. Polymerase chain reaction (PCR) has been used to try to identify molecular markers suitable for distinguishing truffle species during their life cycle [5]. The use of Simple Sequence Repeat (SSR) also showed the possibility to use a molecular marker to trace the $T$. magnatum life cycle [6]. The results are encouraging, but different environmental origins of the fruiting bodies cannot be determined using these methods.

A proteomic approach to resolving this problem therefore appeared suitable. Initial attempts were made by French groups [7] using fruiting body protein analysis as a taxonomic criterion in superior mushrooms. This method made it possible to differentiate several Tuber species. Later these investigations were extended to other French and Italian samples, again with the aim of distinguishing between species [8]. These results are also encouraging although most efforts were then concentrated on isoenzyme analysis [9] and the problem of differentiating areas of origin within the same species remains unresolved. High-resolution two-dimensional gel electrophoresis (2-DE) has been used in several studies to generate fungal protein maps [10]. Protein variability may originate from alternative splicing, post-translational modifications, and amino and carboxy-terminal modifications. Also, the formation of disulfide bonds, glycosylation, the addition of lipid groups, and partial proteolysis can vary. [11]. The interaction between a particular environment and the genome can generate different proteins, different protein structures (qualitative differences) or proteins in varying amounts (quantitative differences). Recently the haploid genome of Tuber melanosporum has been sequenced [4], marking a step forward in understanding of the biology and evolution of ectomycorrhizal symbiosis. The identification of proteins of this species, as well as in others in the same genus, has been significantly facilitated.

Based on these considerations, we have used two dimensional electrophoresis; image and statistical analysis; mass spectrometry; database search and protein blast, to compare protein profiles of fruiting bodies of T. magnatum Pico, naturally grown in different Italian areas, with the aim of characterizing them. In this first contribution some proteins that could enable to distinguish origin of fruiting bodies are reported, while a thorough characterization of them would follow in the near future.

\section{Results and discussion}

Samples collected in two years (as described in Methods -section "fruiting bodies") from different parts of Italy were used for proteomic analysis. The degree of maturation of fruiting bodies was measured according to [12] and reported as stage 5 , with the presence of $80-100 \%$ mature spores that were yellow-reddish brown in color with reticulate ornamentation [13]. At least six independent replicate gels (three for each year analyzed) for all accessions of Tuber were performed. Gels were analyzed for the number of spots, and the intensity and size of the spots. Over 600 reproducible protein spots were detected in each gel. The comparison of protein patterns in different accessions of Tuber revealed the presence of quantitative differences (number of spots) that remained constant in different collecting years (Figure 1, Figure 2).

After bioinformatic analysis, 60 spots showed statistically significant values of ANOVA and fold change which potentially could provide a basis to distinguish between samples. Among these, seventeen were most suitable to describe the area of origin, as assessed by principal component analysis (PCA) and were therefore selected for MS analysis (Figure 1, Figure 2, Figure 3). The PCA results (Figure 3), showed that it is possible to distinguish between samples from different regions (Tuscany, Piedmont, Marche, Umbria) by examining on the expression level of these 17 spots. As it is shown in Figure 2 the difference in expression level of specific spots contribute to the generation of cluster. For instance spots 2 and 8 strongly contribute to form a cluster that include the Umbria samples, being the average normalized intensity values lower than the other accession areas (Figure 2), while the spots 6 and 7 were able to distinguish samples coming from Piedmont (Alba 1 and 2). On the other hand, the sample collected in the Marche region on the other hand, may be identified by spot 12 , while the accessions from Tuscany (the largest group), showed consistently differences for spots 3 and 5 (Figure 2). Furthermore, a post-analysis test for the ANOVA results comparing pairs of samples (Figure 4) showed that some samples are differentiable within the area of origin (namely Tuscany). For example, the sample Crete Senesi, presents the differences of expression in spots 1 and 3, while spots 4 and 10 distinguish the sample Lucca from the others.

Mass spectrometry analysis allowed to get a protein sequence for 15 out of 17 spots. Two spots (10 and 12) 


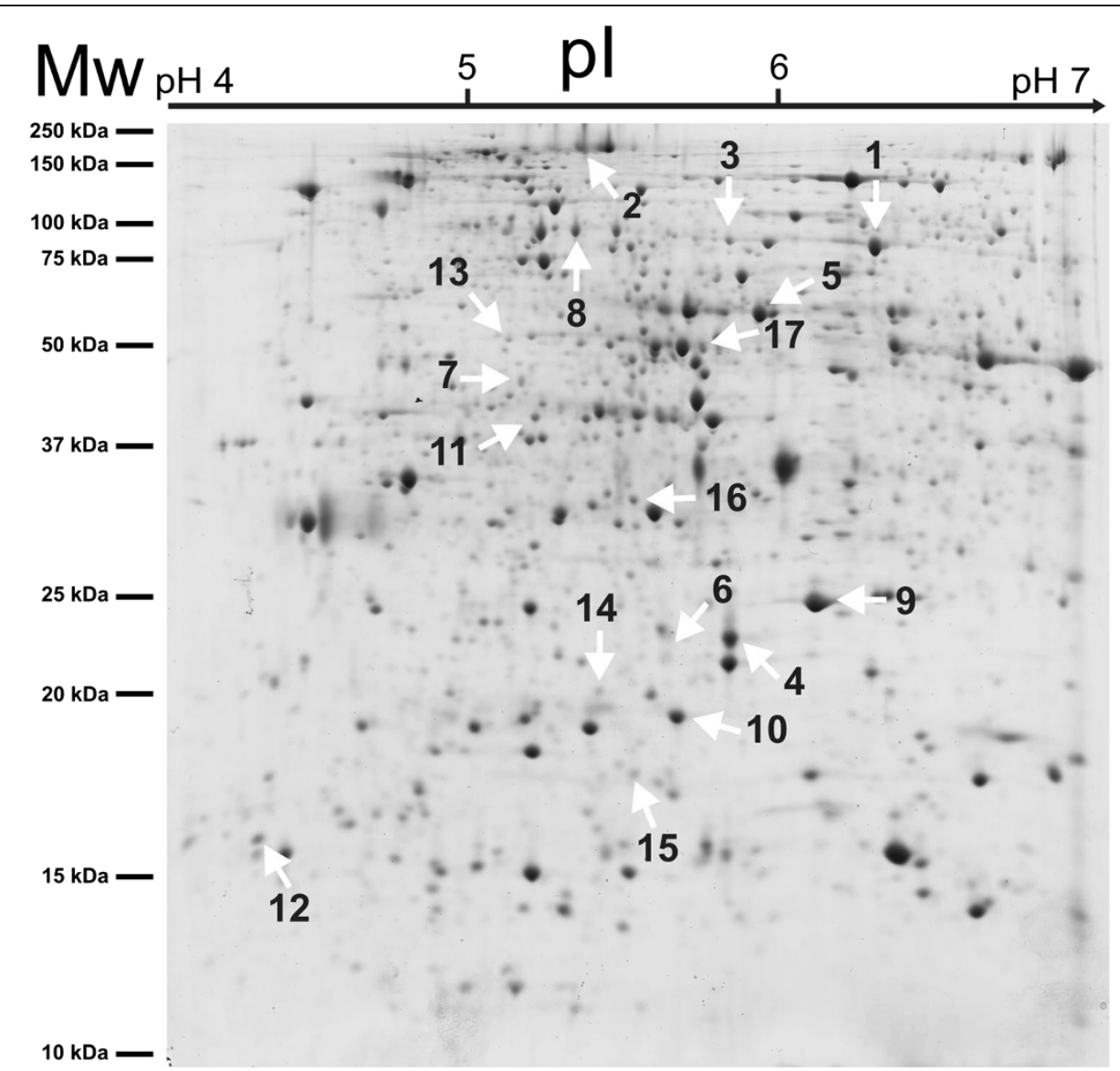

Figure 1 Representative 2D gel from the San Miniato sample (1 $\mathrm{mg}$ of protein extract) stained with colloidal Coomassie. Spots selected by bioinformatic analysis to discriminate between different area of origin as shown here.

failed to give protein identifications while spots 5, 13, 16 and 17 gave rise to the identification of two different proteins in each spot. 17 different proteins were identified (16 through ESI-TOF analysis and 1 by MALDI analysis) even though in spots 2 and 8 , and 6 and 9 different isoform of the same proteins were identified (Table 1, Table 2). All of the proteins, with the exception of Q1ACW3 (NADP-dependent mannitol dehydrogenase) had been previously found in T. melanosporum (Table 1). To ensure a putative functional identification, protein blast (UniprotKB) was performed when no other information was available.

Some of the proteins identified can be grouped according to the metabolic pathways that they belong to. Spots 4 and 5 belong to the methionine metabolism. Spot 5 (Table 1, Table 2) is a S-adenosylmethionine synthetase; this enzyme, similarly to the peptide methionine sulfoxide reductase (spot 4 , Table 1 , Table 2), could function protecting cell against oxidative damage [14]. $\mathrm{S}$-adenosylmethionine synthase appears to take part in cystein/methionine biosynthesis and interconversion, playing a key role in the production of hydrogen sulfide [4]. Hydrogen sulfide is a precursor of many volatile compounds, two of which, dimethyl trisulfide and dimethyl disulfide [15], are among the main volatile compounds responsible for the $T$. magnatum flavor. Other proteins can be grouped on the basis of their redox activity. Dihydrolipoyl dehydrogenase (spot 3), plays a role in cell redox homeostasis, while glyoxal oxidase (spot 2 and 8) catalyzes the oxidation of several aldehydes producing extracellular $\mathrm{H}_{2} \mathrm{O}_{2}$ [16]. It is interesting to observe that glyoxal oxidase shares some traits with another fungal enzyme, galactose oxidase. The critical active site residues typical of radical copper oxidases are conserved between these two enzymes [17]. Galactose oxidase catalyzes the oxidation of primary alcohols to aldehydes and is reported to be a monomeric enzyme of $68.5 \mathrm{kDa}$ [18], though previously was considered a dimer or higher polymer [19]. In our work glyoxal oxidase has been identified at two different molecular weights (91 and $162 \mathrm{kDa}$ ), although at the same pI. Also the intensity values are similar for both spots and correlate well 


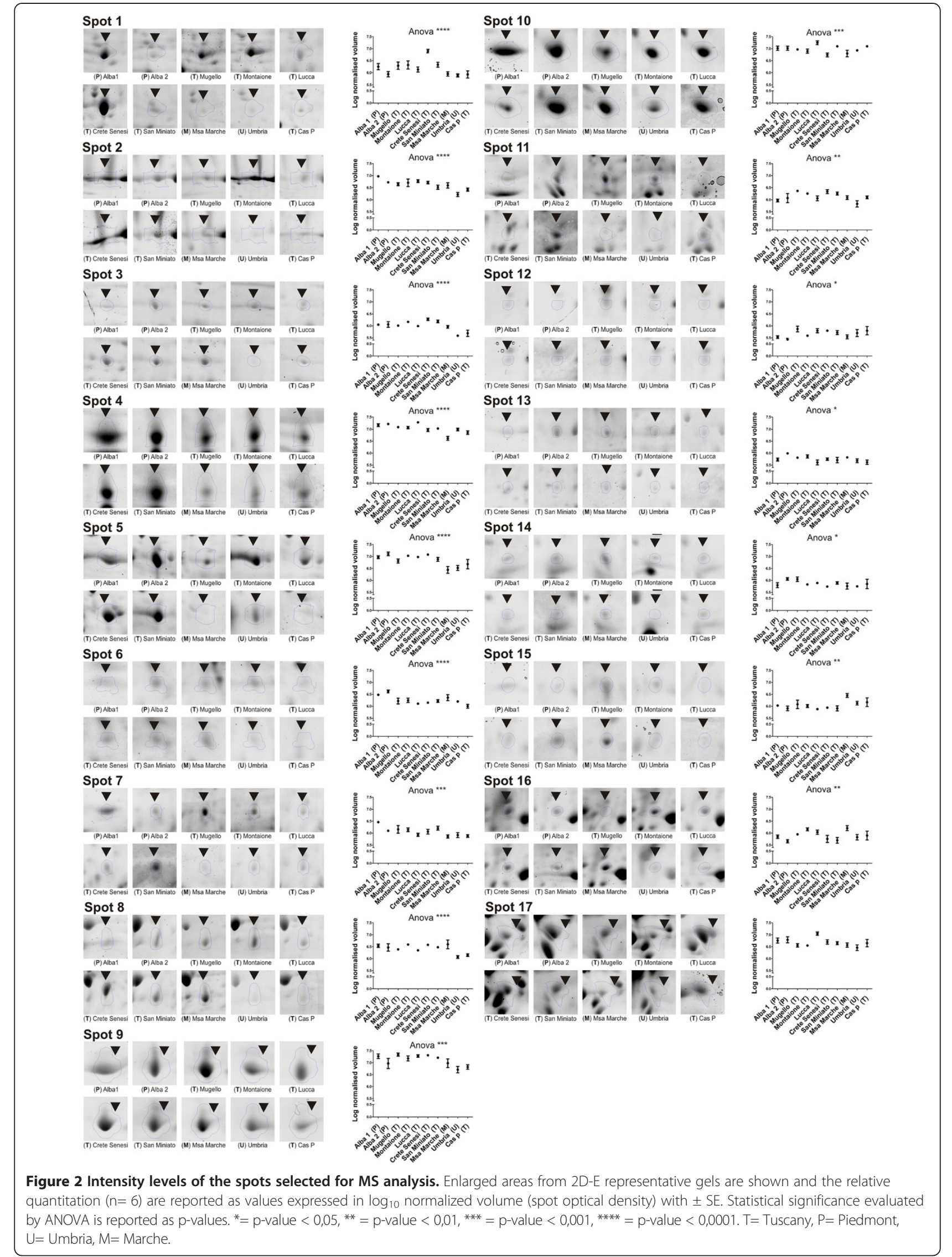




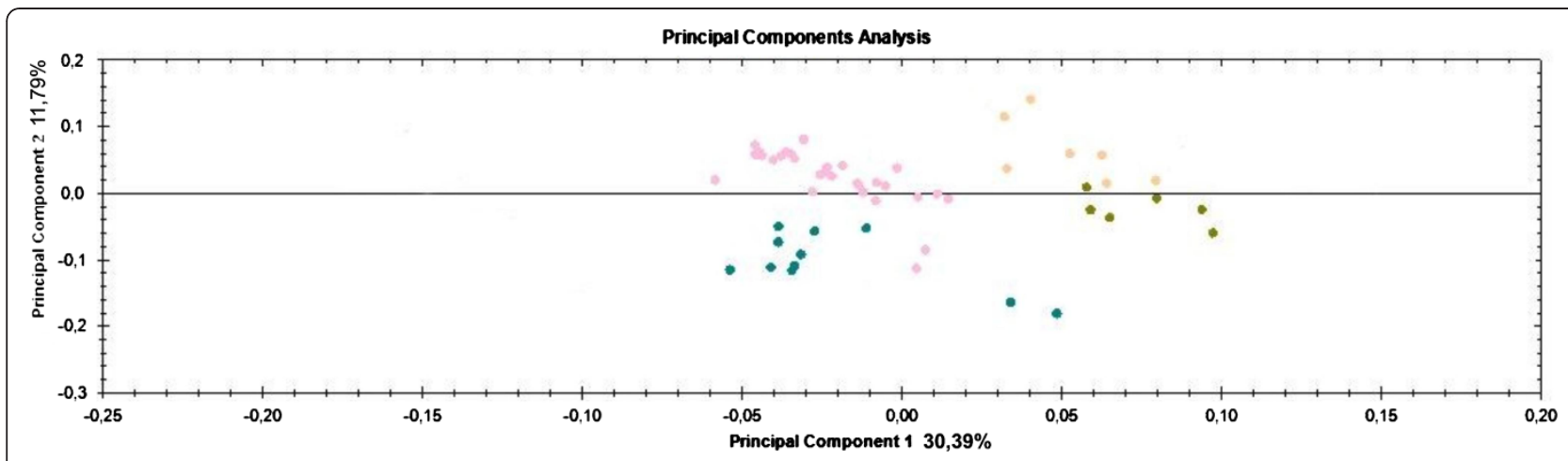

Figure 3 Principal component Analysis obtained on the base of the ability of the 17 spots to discriminate the area of origin. Pink circles represent Tuscany's samples; Green olive circles represent Umbria samples; Yellow circles represent Marche samples; Blue circles represent Piedmont samples.

with transcript data, as demonstrated by Alba 1 and Umbria samples that represent respectively the highest and lowest expression level.

In order to obtain further data in addition to protein identification, we performed a gene expression analysis through qPCR on selected genes. Two technical replicates were performed for each qPCR analysis. When it was not possible to design specific primers (e.g. malate dehydrogenase) due to lack of information, no data were obtained. qPCR was also useful in the case of double protein identification, to try to determine which of the two is responsible for the expression changes observed between truffles of different origin. 10 out of 17 genes related to as many proteins were analyzed by this method. For the remaining 7 genes, it proved impossible to select an efficient set of primer due to the current lack of sequence information. The genes analyzed in the Lucca sample present low levels of expression when compared to all other samples, probably due to the quality of the RNA that was lower than in others. With the exception of this sample, the gene expression data generally correlated well with the related protein levels, as shown by spot 2 and 7 (Figure 2, Figure 5). In spot 2, both the protein levels of D5GJY5 (putative glyoxal oxidase, Table 1, Table 2) and the corresponding transcripts were highest in the Crete Senesi sample. The same was true for spot 7 (D5GAF9, putative pyridoxine biosynthesis protein, Table 1, Table 2), in which both protein and transcript levels were highest in the San Miniato sample. In four cases (spots 5, 13, 16 and 17) two proteins were identified for each spot. For these, both the relative transcripts were analyzed, except for spot 16 . As shown in Figure 5, transcript levels for spot 5 (protein D5G9M7), fit the trend. Similarly in spot 13, the transcript level related to protein D5GAC6 is well correlated with the spot trend. This may suggest that those proteins are the ones that contribute the most to the difference of intensity detected in spot 5 and 13 .

\section{Conclusions}

The aim of this research was to assess protein profiles of fruiting bodies of T. magnatum grown in two years from different areas of Italy. We harvested truffles, in successive years, from the same location (when possible, from the same plant). As shown in our results, we identified several proteins vary according to the place of origin, but that do not change from one year to the next. Although a complete characterization of the T. magnatum fruiting body proteome would require further work, to our knowledge, the proteins identified in this work represent the first contribution on this subject. This was achieved in part thanks to the recent sequencing of T. melanosporum which greatly improved the likelihood of correctly identifying proteins in an organism belonging to the same genus whose proteome has not yet been studied. It was the availability of this basic information which made possible the recognition of several proteins.

These proteins (reported in Table 1, Table 2) have biochemically distinct functions, only some of them belonging to the same pathway. Considering this, together with the very limited proteome coverage that our initial approach afforded, general biochemical or physiological comments could be somewhat preliminary. Also, we decided to MS-analyze only those spots that were statistically significant after image analysis and not all the entire proteome displayed on the gels, since they better characterized the different accession areas.

The fungus is an organism that is not autotrophic and hence relies on plant-originated carbohydrate breakdown in order to get energy for its metabolism. NADPdependent mannitol dehydrogenase is linked to the carbohydrate metabolism [20]. This enzyme catalyzes the conversion of mannitol to mannose, but it can also be very active in the reversible conversion of fructose to mannitol [21]. It seems logical that fruiting bodies originated in different environments are modulated in the subtle though fundamental carbohydrate metabolism pathways. 

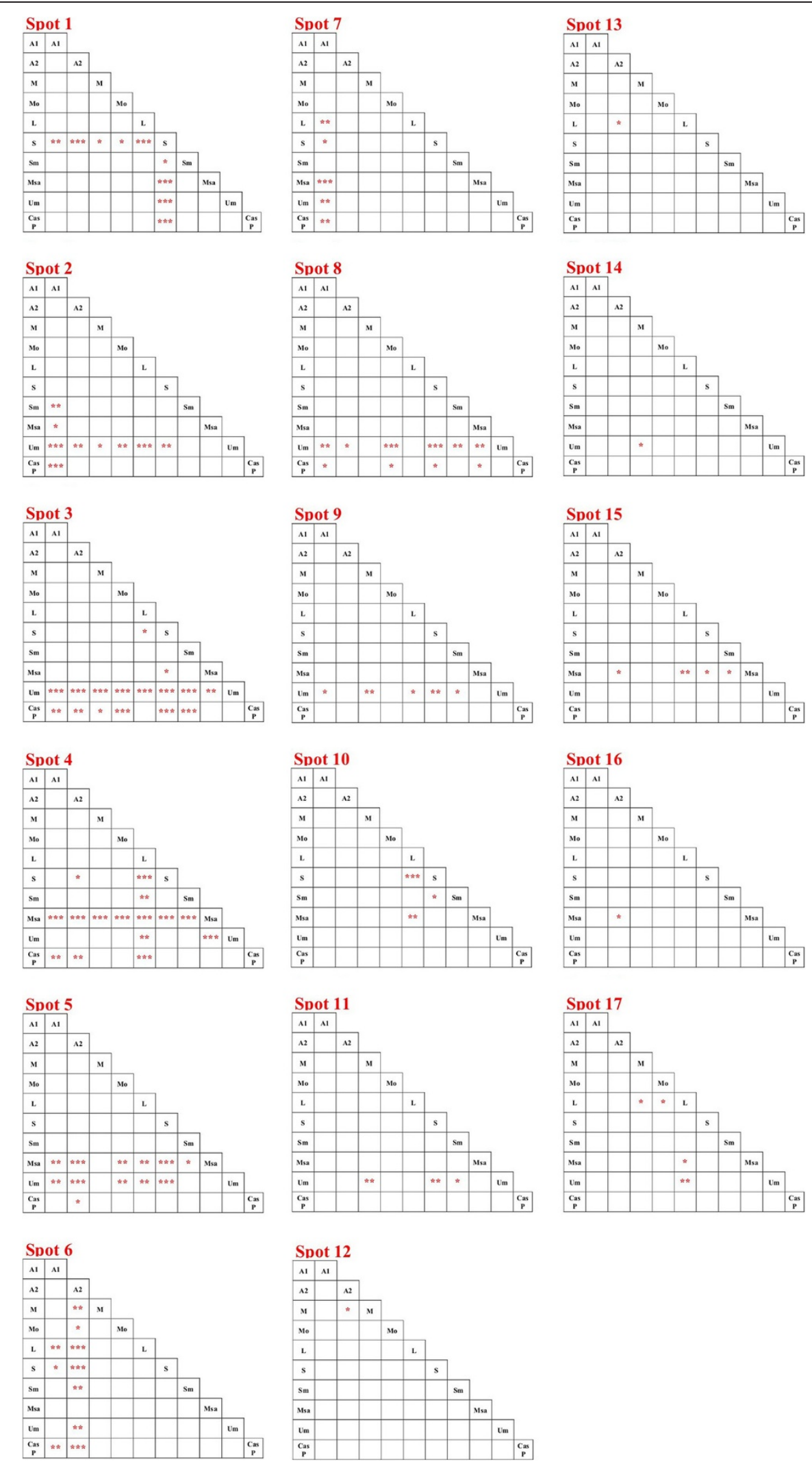

Figure 4 Tukey post test results, performed on the base of the ANOVA results, for the comparison of samples's pairs. ${ }^{*}=p$ value $<0,05$, ${ }^{* *}=\mathrm{p}$-value $<0,01,{ }^{* * *}=\mathrm{p}$-value $<0,001,{ }^{* * * *}=\mathrm{p}$-value $<0,0001 ; \mathrm{A} 1=\mathrm{Alba}, \mathrm{A} 2=$ Alba $2, \mathrm{M}=$ Mugello, Mo $=$ Montaione, $\mathrm{L}=\mathrm{Lucca}, \mathrm{S}=\mathrm{Crete}$ Senesi, $\mathrm{Sm}=$ San Miniato, Msa $=$ Marche, Um = Umbria, Cas $\mathrm{P}=$ Casentino. 
Table 1 Proteins identified by ESI-Quad TOF and MALDI analysis

\begin{tabular}{|c|c|c|c|c|c|c|c|c|c|c|c|c|c|c|}
\hline \multicolumn{15}{|c|}{ ESI } \\
\hline $\begin{array}{l}\text { Spot } \\
\text { No. (a) }\end{array}$ & $\begin{array}{l}\text { Acc. No. } \\
\text { (b) }\end{array}$ & Organism & Protein Description & $\begin{array}{l}\text { Score } \\
\text { (c) }\end{array}$ & $\begin{array}{l}\text { Seq. Cov. } \\
\% \text { (d) }\end{array}$ & $\begin{array}{l}\text { Mw k } \\
\text { Obs// }\end{array}$ & ha & $\begin{array}{l}\text { pl } 0 \\
\text { The }\end{array}$ & $\begin{array}{l}\text { bss/ } \\
\text { o (f) }\end{array}$ & $\begin{array}{l}\text { Identified } \\
\text { peptides } \\
\text { (MS/MS) (g) }\end{array}$ & $\begin{array}{l}\text { Tuber Gene } \\
\text { annotation (h) }\end{array}$ & $\begin{array}{l}\text { KOG } \\
\text { Definition (i) }\end{array}$ & $\begin{array}{l}\text { PFAM } \\
\text { Definition (I) }\end{array}$ & $\begin{array}{l}\text { Protein } \\
\text { Blast } \\
\text { relation } \\
\text { (m) }\end{array}$ \\
\hline 1 & D5G797 & $\begin{array}{l}\text { T. melanosporum } \\
\text { (Perigord truffle) }\end{array}$ & $\begin{array}{l}\text { Whole genome } \\
\text { shotgun sequence } \\
\text { assembly, } \\
\text { scaffold_131, } \\
\text { strain Mel28 }\end{array}$ & 104 & 4 & 78 & 46,2 & 6,2 & 5,82 & 2 & GSTUM_00002523001 & $\begin{array}{l}\text { Aminoacylase } \\
\text { ACY1 }\end{array}$ & Peptidase M20 & A \\
\hline 2 & D5GJY5 & $\begin{array}{l}\text { T. melanosporum } \\
\text { (Perigord truffle) }\end{array}$ & $\begin{array}{l}\text { Whole genome } \\
\text { shotgun sequence } \\
\text { assembly, scaffold_55, } \\
\text { strain Mel28 }\end{array}$ & 378 & 11 & 162 & 86,3 & 5,4 & 5,16 & 7 & GSTUM_00009270001 & $\begin{array}{l}\text { Ultrahigh sulfur } \\
\text { keratin-associated } \\
\text { protein }\end{array}$ & Glyoxal oxidase & B \\
\hline 3 & D5GGN7 & $\begin{array}{l}\text { T. melanosporum } \\
\text { (Perigord truffle) }\end{array}$ & $\begin{array}{l}\text { Dihydrolipoyl } \\
\text { dehydrogenase }\end{array}$ & 137 & 6 & 81 & 54 & 5,7 & 6,72 & 3 & GSTUM_00007439001 & $\begin{array}{l}\text { Dihydrolipoamide } \\
\text { dehydrogenase }\end{array}$ & $\begin{array}{l}\text { Pyridine nucleotide- } \\
\text { disulphide } \\
\text { oxidoreductase }\end{array}$ & \\
\hline 4 & D5G8F0 & $\begin{array}{l}\text { T. melanosporum } \\
\text { (Perigord truffle) }\end{array}$ & $\begin{array}{l}\text { Whole genome } \\
\text { shotgun sequence } \\
\text { assembly, scaffold_15, } \\
\text { strain Mel28 }\end{array}$ & 164 & 28 & 22,5 & 20 & 5,7 & 5,41 & 4 & GSTUM_00004791001 & $\begin{array}{l}\text { Peptide } \\
\text { methionine } \\
\text { sulfoxide } \\
\text { reductase }\end{array}$ & $\begin{array}{l}\text { Peptide methionine } \\
\text { sulfoxide reductase }\end{array}$ & C \\
\hline \multirow[t]{2}{*}{5} & D5GJ78 & $\begin{array}{l}\text { T. melanosporum } \\
\text { (Perigord truffle) }\end{array}$ & $\begin{array}{l}\text { S-adenosyl methionine } \\
\text { synthase }\end{array}$ & 871 & 47 & 57 & 41,8 & 5,8 & 5,7 & 15 & GSTUM_00008874001 & $\begin{array}{l}\text { S-adenosylmeth. } \\
\text { synthetase }\end{array}$ & $\begin{array}{l}\text { S-adenosylmeth. } \\
\text { synthetase }\end{array}$ & \\
\hline & D5G9M7 & $\begin{array}{l}\text { T. melanosporum } \\
\text { (Perigord truffle) }\end{array}$ & $\begin{array}{l}\text { Whole genome shotgun } \\
\text { sequence assembly, } \\
\text { scaffold_169, strain Mel28 }\end{array}$ & 114 & 12 & 57 & 57,8 & 5,8 & 9,93 & 5 & GSTUM_00003332001 & $\begin{array}{l}\text { RNA-binding } \\
\text { protein }\end{array}$ & $\begin{array}{l}\text { RNA recognition } \\
\text { motif }\end{array}$ & D \\
\hline 6 & D5GNA2 & $\begin{array}{l}\text { T. melanosporum } \\
\text { (Perigord truffle) }\end{array}$ & $\begin{array}{l}\text { Whole genome shotgun } \\
\text { sequence assembly, } \\
\text { scaffold_8, strain Mel28 }\end{array}$ & 125 & 22 & 22 & 22 & 5,5 & 6,21 & 4 & GSTUM_00011192001 & $\begin{array}{l}\text { 1,4-benzoquinone } \\
\text { reductase }\end{array}$ & Flavodoxin & $\mathrm{E}$ \\
\hline 7 & D5GAF9 & $\begin{array}{l}\text { T. melanosporum } \\
\text { (Perigord truffle) }\end{array}$ & $\begin{array}{l}\text { Whole genome shotgun } \\
\text { sequence assembly, } \\
\text { scaffold_18, strain Mel28 }\end{array}$ & 146 & 8 & 45 & 33 & 5,1 & 6,02 & 4 & GSTUM_00005271001 & $\begin{array}{l}\text { Stationary phase- } \\
\text { induced protein }\end{array}$ & SOR/SNZ family & $\mathrm{F}$ \\
\hline 8 & D5GJY5 & $\begin{array}{l}\text { T. melanosporum } \\
\text { (Perigord truffle) }\end{array}$ & $\begin{array}{l}\text { Whole genome shotgun } \\
\text { sequence assembly, } \\
\text { scaffold_55, strain Mel28 }\end{array}$ & 170 & 9 & 91 & 86,3 & 5,4 & 5,16 & 6 & GSTUM_00009270001 & $\begin{array}{l}\text { Ultrahigh sulfur } \\
\text { keratin-associated } \\
\text { protein }\end{array}$ & Glyoxal oxidase & \\
\hline 9 & D5GNA2 & $\begin{array}{l}\text { T. melanosporum } \\
\text { (Perigord truffle) }\end{array}$ & $\begin{array}{l}\text { Whole genome shotgun } \\
\text { sequence assembly, } \\
\text { scaffold_8, strain Mel } 28\end{array}$ & 1206 & 35 & 25 & 22 & 6,1 & 6,21 & 6 & GSTUM_00011192001 & $\begin{array}{l}\text { 1,4-benzoquinone } \\
\text { reductase }\end{array}$ & Flavodoxin & G \\
\hline 11 & D5G6L6 & $\begin{array}{l}\text { T. melanosporum } \\
\text { (Perigord truffle) }\end{array}$ & $\begin{array}{l}\text { Whole genome shotgun } \\
\text { sequence assembly, } \\
\text { scaffold_121, strain Mel28 }\end{array}$ & 118 & 21 & 41 & 31,3 & 5,2 & 6,01 & 5 & GSTUM_00002097001 & $\begin{array}{l}\text { Predicted } \\
\text { dehydrogenase }\end{array}$ & $\begin{array}{l}\text { Short chain } \\
\text { dehydrogenase }\end{array}$ & \\
\hline 13 & D5GC43 & $\begin{array}{l}\text { T. melanosporum } \\
\text { (Perigord truffle) }\end{array}$ & $\begin{array}{l}\text { Whole genome shotgun } \\
\text { sequence assembly, } \\
\text { scaffold_201, strain Mel28 }\end{array}$ & 149 & 18 & 38 & 33,5 & 5.1 & 5,06 & 5 & GSTUM_00000555001 & $\begin{array}{l}\text { Lysophosphatidic } \\
\text { acid acyltransferase }\end{array}$ & $\begin{array}{l}\text { BAR domain } \\
\text { protein }\end{array}$ & $\mathbf{H}$ \\
\hline
\end{tabular}


Table 1 Proteins identified by ESI-Quad TOF and MALDI analysis (Continued)

\begin{tabular}{|c|c|c|c|c|c|c|c|c|c|c|c|c|c|c|}
\hline & D5GAC6 & $\begin{array}{l}\text { T. melanosporum } \\
\text { (Perigord truffle) }\end{array}$ & $\begin{array}{l}\text { Probable Xaa-Pro } \\
\text { aminopeptidase }\end{array}$ & 131 & 5 & 38 & 69,2 & 5.1 & 5,28 & 3 & GSTUM_00005237001 & $\begin{array}{l}\text { Xaa-Pro } \\
\text { aminopeptidase }\end{array}$ & Peptidase_M24 & \\
\hline 14 & D5GCN2 & $\begin{array}{l}\text { T. melanosporum } \\
\text { (Perigord truffle) }\end{array}$ & $\begin{array}{l}\text { Whole genome shotgun } \\
\text { sequence assembly, } \\
\text { scaffold_218, strain Mel28 }\end{array}$ & 83 & 22 & 19 & 20,7 & 5.4 & 8,64 & 3 & GSTUM_00000743001 & $\begin{array}{l}\text { Alkyl hydroperoxide } \\
\text { reductase/ } \\
\text { peroxiredoxin }\end{array}$ & Redoxin & 1 \\
\hline 15 & D5G620 & $\begin{array}{l}\text { T. melanosporum } \\
\text { (Perigord truffle) }\end{array}$ & Malate dehydrogenase & 115 & 8 & 18 & 36,7 & 5.5 & 8,79 & 3 & GSTUM_00001731001 & $\begin{array}{l}\text { NAD-dependent } \\
\text { malate } \\
\text { dehydrogenase }\end{array}$ & $\begin{array}{l}\text { Lactate/malate } \\
\text { dehydrogenase }\end{array}$ & \\
\hline 16 & D5GE86 & $\begin{array}{l}\text { T. melanosporum } \\
\text { (Perigord truffle) }\end{array}$ & $\begin{array}{l}\text { Whole genome shotgun } \\
\text { sequence assembly } \\
\text { scaffold_26, strain Mel28 }\end{array}$ & 105 & 14 & 28,2 & 26,8 & 5.5 & 7,1 & 4 & GSTUM_00006427001 & $\begin{array}{l}\text { Predicted } \\
\text { hydrolases of HD } \\
\text { superfamily }\end{array}$ & No Hit Found & $\mathrm{L}$ \\
\hline \multirow[t]{2}{*}{17} & D5G5R4 & $\begin{array}{l}\text { T. melanosporum } \\
\text { (Perigord truffle) }\end{array}$ & $\begin{array}{l}\text { Whole genome shotgun } \\
\text { sequence assembly, } \\
\text { scaffold_112, strain Mel28 }\end{array}$ & 376 & 11 & 45,6 & 46,9 & 5.7 & 5,97 & 4 & GSTUM_00001447001 & $\begin{array}{l}\text { Fructose 1,6- } \\
\text { bisphosphate } \\
\text { aldolase }\end{array}$ & $\begin{array}{l}\text { Fructose- } \\
\text { bisphosphate } \\
\text { aldolase }\end{array}$ & $M$ \\
\hline & Q1ACW3 & Tuber borchii & $\begin{array}{l}\text { NADP-dependent } \\
\text { mannitol dehydrogenase }\end{array}$ & 314 & 26 & 45,6 & 38 & 5.7 & 5,69 & 7 & DQ223686.1 & $\begin{array}{l}\text { NAD-dependent } \\
\text { malate } \\
\text { dehydrogenase }\end{array}$ & $\begin{array}{l}\text { NAD-dependent } \\
\text { malate } \\
\text { dehydrogenase }\end{array}$ & \\
\hline \multicolumn{15}{|c|}{ MALDI } \\
\hline $\begin{array}{l}\text { Spot } \\
\text { No. (a) }\end{array}$ & $\begin{array}{l}\text { Acc. No. } \\
\text { (b) }\end{array}$ & Organism & Protein Description & $\begin{array}{l}\text { Score } \\
\text { (c) }\end{array}$ & $\begin{array}{l}\text { Seq. Cov. } \\
\% \text { (d) }\end{array}$ & $\begin{array}{l}\text { Mw k } \\
\text { Obs/T }\end{array}$ & $\begin{array}{l}\mathrm{Da} \\
\text { heo (e) }\end{array}$ & $\begin{array}{l}\text { pl } 0 \\
\text { The }\end{array}$ & ofs/ & $\begin{array}{l}\text { Identified } \\
\text { peptides } \\
\text { (MS) (g) }\end{array}$ & $\begin{array}{l}\text { Tuber Gene } \\
\text { annotation (h) }\end{array}$ & $\begin{array}{l}\text { KOG } \\
\text { Definition (i) }\end{array}$ & $\begin{array}{l}\text { PFAM } \\
\text { Definition (I) }\end{array}$ & $\begin{array}{l}\text { Protein } \\
\text { Blast } \\
\text { relation } \\
(\mathrm{m})\end{array}$ \\
\hline 16 & D5GJE0 & $\begin{array}{l}\text { T. melanosporum } \\
\text { (Perigord truffle) }\end{array}$ & $\begin{array}{l}\text { Whole genome shotgun } \\
\text { sequence assembly, } \\
\text { scaffold_50, strain Mel28 }\end{array}$ & 80 & $40 \%$ & 28.2 & 25.6 & 5.5 & 5.77 & 11 & GSTUM_00008955001 & $\begin{array}{l}\text { Alkyl hydroperoxide } \\
\text { reductase }\end{array}$ & $\begin{array}{l}\text { AhpC-TSA, AhpC/ } \\
\text { TSA family }\end{array}$ & \\
\hline
\end{tabular}


Table 2 Additional information on the proteins obtained by blast analysis

\begin{tabular}{|c|c|c|c|c|c|c|}
\hline Spot No. (a) & $\begin{array}{l}\text { Protein Blast } \\
\text { relation (b) }\end{array}$ & Acc. No. (c) & Protein Name & Organism & Protein Length (d) & E-Value (e) \\
\hline 1 & A & G2YT91 & $\begin{array}{l}\text { Similar to peptidase } \\
\text { (Secreted protein) }\end{array}$ & Botryotinia fuckeliana & 383 & $1.0 \times 10^{-120}$ \\
\hline 2,8 & B & B2WA62 & Glyoxal oxidase & Pyrenophora tritici-repentis & 825 & 0.0 \\
\hline 4 & $\mathrm{C}$ & B2WK75 & $\begin{array}{l}\text { Peptide methionine sulfoxide } \\
\text { reductase } \mathrm{msrB} / \mathrm{msrA}\end{array}$ & Pyrenophora tritici-repentis & 184 & $3.0 \times 10^{-96}$ \\
\hline 5 & D & Q4WLU4 & RNP domain protein & Neosartorya fumigata & 480 & $1.0 \times 10^{-120}$ \\
\hline 6,9 & $\mathrm{E}$ & C4JW16 & $\begin{array}{l}\text { NAD(P)H:quinone oxidoreductase, } \\
\text { type IV }\end{array}$ & Uncinocarpus reesii & 203 & $1.0 \times 10^{-100}$ \\
\hline 7 & $F$ & E5ABQ9 & $\begin{array}{l}\text { Similar to pyridoxine } \\
\text { biosynthesis protein }\end{array}$ & Leptosphaeria maculans & 307 & $1.0 \times 10^{-176}$ \\
\hline 11 & G & C5FLT9 & $\begin{array}{l}\text { 3-oxoacyl-[acyl-carrier-protein] } \\
\text { reductase }\end{array}$ & Arthroderma otae & 289 & $2.0 \times 10^{-92}$ \\
\hline 13 & $\mathrm{H}$ & A4D9A0 & BAR protein & Neosartorya fumigata & 305 & $1.0 \times 10^{-137}$ \\
\hline 14 & $\mathrm{I}$ & B8MCW9 & AhpC/TSA family protein & Talaromyces stipitatus & 181 & $3.0 \times 10^{-50}$ \\
\hline 16 & $\mathbf{L}$ & C1G7T9 & HD domain-containing protein & Paracoccidioides brasiliensis & 224 & $4.0 \times 10^{-62}$ \\
\hline 17 & $M$ & GORU75 & Fructose bisphosphate aldolase & Hypocrea jecorina & 360 & 0.0 \\
\hline
\end{tabular}

Table 2 Protein Blast results of the identified proteins mentioned in Table 2. (a) as indicated in Figure 1; (b) alphabetical correlation to proteins previously reported (Table 2); (c) UniProtKB, accession number; (d) as reported from blast output; (e) Expect value, the lower the E-value the higher is the "significance" of the match.

Sugars are channeled to glycolysis and the TCA cycle to produce energy and metabolites. A TCA cycle enzyme (malate dehydrogenase) is one of the proteins affected by the environment giving support to the idea that the fungal respiratory metabolism is influenced. Alternatively this enzyme could be involved in the glyoxylate cycle and hence in the gluconeogenesis pathway [22] with its peculiar dual function.

Protein D5GJY5, identified as glyoxal oxidase with a good e-value after protein blast analysis, represents an interesting protein that is important for lignin degradation through production of extracellular $\mathrm{H}_{2} \mathrm{O}_{2}$. [16,23]. On the other hand T. magnatum moves along differential nutritional strategies (saprotrophic, endophytic and symbiotic) depending on the environment and on the developmental phase of their life cycle [24].

For the remaining identified proteins it is more difficult to extrapolate specific physiological meanings, even though all of them have important biological functions.

Certainly with these results we have shown that several proteins of T. magnatum, a species whose genome at the moment is not still sequenced, could be identified and a specific biochemical role can be assigned to them; with more high-throughput proteomic analysis, planned for the future, a more definitive physiological frame could be available.

The results of this study show how it is possible to use a proteomic approach to verify the consistency of quantitative variation of proteins of interest. The results showed a high reproducibility of the patterns from samples collected in different years. We have individuated 17 proteins from T. magnatum Pico, which provide a basis for the future development of proteomic characterization of fruiting bodies of different origin.

\section{Methods}

\section{Fruiting bodies}

Fruiting bodies belonging to the various T. magnatum accessions were collected from natural ground in central and northern Italy (Tuscany, Piedmont, Marche and Umbria) in two successive years as reported in Table 3. At least three fruiting bodies were used for each biological replicate and their protein extracts were then mixed to increase the homogeneity of the sample. Fruiting bodies were thoroughly washed several times with distilled water and subsequently dipped in absolute ethyl alcohol to remove external contamination. Finally the thin external layer of the peridium was removed. Microbiological analysis, carried out to verify the presence of micro-organisms inside the gleba (inner tissue of the fruiting bodies), showed that after ethanol treatment the residual microbial contaminants were still present, but the number of CFU were reduced to such a low level that the detection of their proteins would not be possible (data not shown). Samples were frozen in liquid nitrogen and the tissue was ground in a mortar, then stored at $-80^{\circ} \mathrm{C}$ before being used for protein analysis.

\section{Protein extraction}

Fruiting bodies (100 mg) were ground in liquid nitrogen and homogenized with $1.6 \mathrm{~mL}$ of extraction buffer (Urea $8 \mathrm{M}$, Tris- $\mathrm{HCl} 40 \mathrm{mM}$ CHAPS 4\%, DTT $60 \mathrm{mM}$ ) according to [25] with some modifications. The homogenates were centrifuged for $15 \mathrm{~min}$ at $13.000 \mathrm{rcf}$ at $4^{\circ} \mathrm{C}$ 


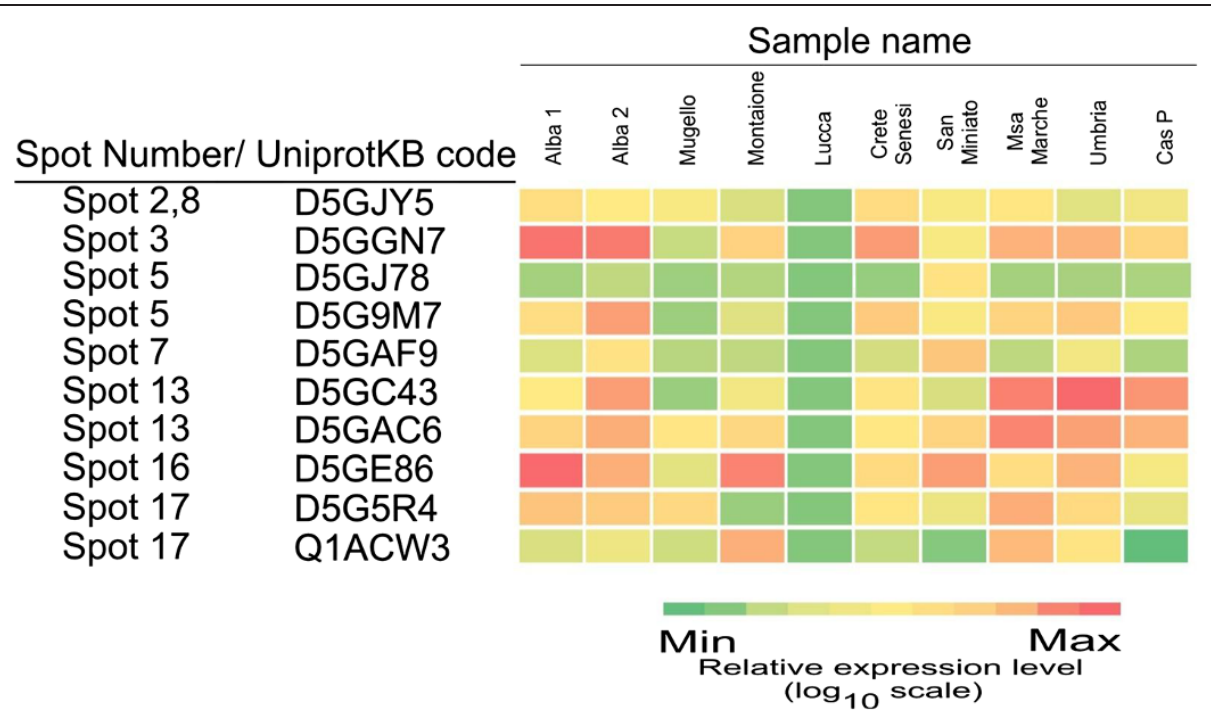

Figure 5 Coordinate regulation of gene related proteins. The Lucca sample was selected as internal control and it represents the less expressed sample. $(n=4)$ Cas $P=$ Casentino.

in order to eliminate debris. Supernatants, containing extracted proteins, were precipitated using 13\% TCA and $0.007 \%$ ß-mercaptoethanol in acetone, transferred to $-20^{\circ} \mathrm{C}$ for $2 \mathrm{hrs}$ and finally kept at $4^{\circ} \mathrm{C}$ for $2 \mathrm{hrs}$.

Samples were then centrifuged at $14000 \mathrm{rcf}$ at $4^{\circ} \mathrm{C}$ for $15 \mathrm{~min}$ and the pellet was washed twice with cold acetone $(100 \%)$, re-centrifuged at the same speed, mixed with 50-500 $\mu \mathrm{L}$ extraction buffer and centrifuged at $3000 \mathrm{rcf}$ at $4^{\circ} \mathrm{C}$ for $25 \mathrm{~min}$. Protein quantification was done by Bradford assay (BIO-RAD Hercules, CA) using Bovine serum albumin (BSA) as standard.

\section{Two-dimensional electrophoresis analysis}

Two dimensional electrophoresis (2DE) analysis was performed combining IsoElectric Focusing (IEF) and Sodium

Table 3 Samples under analysis

\begin{tabular}{cccc}
\hline $\begin{array}{c}\text { Accessions } \\
\text { (Collection place) }\end{array}$ & Host Plant & Region & $\begin{array}{c}\text { Collection } \\
\text { period }\end{array}$ \\
\hline San Miniato & Wood & Tuscany & November 2008-2009 \\
Crete Senesi & Wood & Tuscany & November 2008-2009 \\
Mugello & Tilia sp. & Tuscany & November 2008-2009 \\
Montaione & Wood & Tuscany & November 2008-2009 \\
Lucca & (Populus tremula) & Tuscany & November 2008-2009 \\
Umbria & Wood & Umbria & November 2010-2011 \\
Alba 1 & (Populus tremula) & Piedmont & November 2008-2009 \\
Alba 2 & (Quercus ruber) & Piedmont & November 2008-2009 \\
Msa Marche & (Populus tremula) & Marche & November 2010-2011 \\
\hline
\end{tabular}

Table 3 Samples collected in two years in different Italian areas. In four cases it was not possible to trace back the specific host plant. Msa Marche sample from Sant'Angelo in Vado (PU), Umbria samples from Corciano (PG). Fruiting bodies used for each year of analysis; $2008(n=3), 2009(n=4), 2010(n=3)$ $2011(n=3)$.
Dodecyl Sulfate PolyAcrylamide Gel Electrophoresis (SDS-PAGE) as describe in [26,27]. Samples (1 mg) of protein were directly loaded by in-gel rehydration onto an IPG (Immobilized pH Gradient) gel strip for preparative analysis. IPG strips (18 cm, GE-Healthcare), with $\mathrm{pH}$ range 4-7, were rehydrated with $350 \mu \mathrm{L}$ of IEF sample buffer (8 M urea, 2\% w/v CHAPS, $40 \mathrm{mM} \mathrm{DTT}$ and $0.5 \% \mathrm{v} / \mathrm{v}$ IPG Buffer) containing the samples. Strips were covered with mineral oil and focusing was carried out in a IPGphor apparatus (GE-Healthcare) applying the following conditions: $12 \mathrm{~h}$ of rehydration at $30 \mathrm{~V}, 1 \mathrm{~h}$ at $300 \mathrm{~V}$ (in gradient), $1 \mathrm{~h}$ at $300 \mathrm{~V}$ (step and hold), $3 \mathrm{~h}$ at $3500 \mathrm{~V}$ (in gradient), $3 \mathrm{~h}$ at $3500 \mathrm{~V}$ (step and hold), $3 \mathrm{~h}$ at 8000 $\mathrm{V}$ (in gradient) and a final step at $8000 \mathrm{~V}$ (step and hold until reached 50000 Vhs). After focusing, the strips were equilibrated, in two steps of $15 \mathrm{~min}$ (first stepequilibration buffer: $50 \mathrm{mM}$ Tris- $\mathrm{HCl}, \mathrm{pH} 8.8,8 \mathrm{M}$ urea, $30 \%$ v/v glycerol, 2\% w/v SDS, 40 mM DTT; second stepequilibration buffer: in the same buffer in which DTT was replaced by $40 \mathrm{mM}$ IAA). The second dimension, SDS-PAGE electrophoresis, was performed using BioRad Protean II XL $(20 \times 20 \mathrm{~cm})$ vertical gel electrophoresis chambers. $12 \%$ polyacrylamide gels were run at $15^{\circ} \mathrm{C}$ with a constant current of $40 \mathrm{~mA}$ per gel. Molecular weight standards in a range from 10 to $150 \mathrm{kDa}$ were from BioRad. Proteins resolved by $2 \mathrm{DE}$, were visualized by colloidal Coomassie brilliant-blue staining for both analytical and preparative analyses. For computer analysis, three gels per year were selected (total of six gels for two years) for each sample. The Brilliant Blue G-Colloidal Concentrate Coomassie (Sigma) staining for preparative analysis was performed according to manufacturer's instructions. 


\section{Image analysis and statistical analysis}

High resolution (300 dpi) images were acquired using the ProXpress CCD camera system (Perkin Elmer). Computerassisted 2D image analysis was done using Progenesis SameSpots vs 3.2.3 gel analysis software (NonLinear Dynamics) for three technical replicates for each biological condition (different years) from three independent experiments (see above). Protein apparent relative molecular mass $(\mathrm{Mr}$ ) was estimated by comparison with molecular weight (MW) reference markers (Precision, Bio-Rad, Hercules, CA) and pI values assigned to detected spots by calibration as described in the GE-Healthcare guide lines. The amount of protein was expressed as spot volume, which was defined as the sum of optical density of all the pixels that make up the spot as detected by the software. Protein level increase/decrease was quantified comparing the spot volumes normalized as percentage of the total volume in all the spots present in the gel.

Spots were considered to represent differentially expressed proteins on the basis of their ANOVA values (q-value) and fold change as evaluated by the software. Image software automatically order spots on the base of these values. Post-test analysis (Tukey's test) was performed on the basis of the ANOVA results, in order to identify specific correlations among the samples. The relevance of each spot in discriminating between samples from different places was evaluated by principal component analysis as software tool for different combinations of differentially expressed spots.

\section{Protein identification by MALDI-TOF and nLC-ESI-MSIMS}

Protein spots of interest were excised from gels, reduced, alkylated, and digested overnight with bovine trypsin (Roche Diagnostics Corp.) as previously described by Shevchenko [28]. Aliquots of the supernatant $(1 \mu \mathrm{L})$ were used for MS analysis. MS analysis was done using the dried-droplet technique, with $\alpha$-cyano-4-hydroxycinnamic acid as a matrix. Mass spectra were obtained with a MALDI-TOF Voyager DE-STR from Applied Biosystems/MDS Sciex. Ions were generated by irradiation with a pulsed nitrogen laser (337 nm UV, pulse duration $3 \mathrm{~ns}$, pulse rate $3 \mathrm{~Hz}$ ), and positive ions were accelerated and detected in the reflector mode. Instrument settings were: accelerating $20.000 \mathrm{~V}$, grid $64 \%$, guide wire $0 \%$, delay time 200 ns, shots/spectrum 100, mass range 750$4000 \mathrm{Da}$ and low mass gate $700 \mathrm{Da}$. Spectra were acquired via Voyager Control Panel 5.10 from Applied Biosystems. Once acquired, spectra were processed with Data Explorer 4.0 from Applied Biosystems and internally calibrated with trypsin autolysis products and matrix clusters. MALDI-TOF data led to extracted and manually curated peptide monoisotopic peak lists (deprived from trypsin and matrix clusters signals) that were searched, via in-house Mascot Server 2.2.07, against the target database as detailed below except for mass tolerance for monoisotopic data that was set to $50 \mathrm{ppm}$ and significance threshold of $\mathrm{p}<0.05$ set for the probability based Mascot Mowse Score.

For ESI analysis, $5 \mu \mathrm{L}$ of trypsin digested samples were injected in a capillary chromatographic system Agilent 1100 Series equipped with a Nano Pump, Iso Pump, Degaser and a $8 \mu \mathrm{L}$ injection loop (Agilent). Peptide separations occurred on a 10-15 cm fused silica emitter (75 $\mu \mathrm{m}$ i.d., $360 \mu \mathrm{m}$ o.d.; Proxeon Biosystems) used as analytical RP nano column. The emitter was packed in-house with a methanol slurry of reverse-phase, fully end-capped 3- $\mu \mathrm{m}$ ReproSil-Pur 120 C18-AQ resin (Dr. Maisch GmbH), using a pressurized "packing bomb" operated at 50-60 bars.

Mobile phases consisted of water with $2 \%$ acetonitrile, $0.1 \%$ formic acid (v/v; buffer A) and acetonitrile with $2 \%$ water, $0.1 \%$ formic acid (v/v; buffer B). A 55 -min gradient from $8 \%$ to $80 \%$ buffer $B$ at a constant flow rate of $200 \mathrm{nl} / \mathrm{min}$ was used for peptides separation.

Eluting peptides were ionized by a nanoelectrospray ion source (Proxeon Biosystems) and analyzed on an API QStar PULSAR (PE-Sciex) mass spectrometer. Analyses were performed in positive ion mode. The HV Potential was set up around 1.8-2.0 kV. Full scan mass spectra ranging from m/z 350 to 1600 Da were collected and for each MS spectrum the two most intense doubly and triply charged ions peaks were selected for fragmentation (MS/MS range from m/z 100 to $1600 \mathrm{Da}$ ).

MS/MS spectra data files from each chromatographic run were combined and converted to mgf files using Mascot.dll (version 1.6b27) through Analyst QS 1.1 (Applied Biosystems) and searched (via Mascot Daemon 2.2.2 and in-house Mascot Server 2.2.07), first against a custom contaminant database (trypsin and common keratins partly derived from the cRAP collection), unmatched signals were then searched against the UniProt_Complete Proteome_tuber 2012_07 (7679 sequences; 3339250 residues) database. Mass tolerance was set to $200 \mathrm{ppm}$ and $0.3 \mathrm{Da}$ for precursor and fragment ions respectively. Searches were performed with trypsin specificity, alkylation of cysteine by carbamidomethylation, and oxidation of methionine as fixed and variable modifications respectively; ion score cut-off set to 20; two missed cleavages were allowed for trypsin specificity; the quality of MS/MS identifications was manually checked. Proteins obtained without functional identification were then used for Protein Blast Analysis (UniprotKb blastp) performed with default settings.

\section{Total RNA extraction and real-time PCR analysis}

Total RNA was extracted from pulverized samples as described [29]. This protocol was selected on the basis of its ability to remove contaminants from RNA extracted samples. Electrophoresis using 1\% agarose gel 
was performed for all RNA samples to check for RNA integrity, followed by spectrophotometric quantification and quality control. RNA samples were then subjected to DNase treatment using a Turbo DNA-free kit (Ambion, USA) to remove possible DNA contamination. RNA was then reverse-trascribed using SuperScript ${ }^{\circledR}$ III Reverse Transcriptase kit (Life Technologies, UK) with random primers. Gene expression analysis was carried out using an ABI Prism 7300 sequence detection system (Applied Biosystems, USA) as described by [30]. Quantitative PCR was performed using $30 \mathrm{ng} \mathrm{cDNA}$ and $\mathrm{iQ}^{\mathrm{TM}}$ Sybr Green Supermix (BioRad laboratories), according to the manufacturer's instructions. Two technical replicates were performed for each biological replicate $(n=4)$.

Expression of T. magnatum (AF054901) 18S rRNA was used as a housekeeping gene. Relative expression levels were calculated using Genorm (http://medgen.ugent. be/genorm/). Primers were designed using Primer 3 . The following primer list is reported with its specific Tuber gene identification code (in brakets Uniprot code of the relative protein):

GSTUM_00009270001 (D5GJY5), 5'-gcactggcaccactcctac c-3'(forward), 5'-gaagaaggtgcccccaaaac-3' (reverse); GST UM_00007439001 (D5GGN7), 5'-gaccaggaataccgcaccaa-3' (forward), 5'-tcctcctcagccttgtgagc-3' (reverse); GSTUM_00 008874001 (D5GJ78), 5'-gcgccatcaaggatattgga-3' (forward), 5'-aacaccagtggcgatgtcct-3' (reverse); GSTUM_00003332001 (D5G9M7), 5'-tcctctcgctcgcctatgag-3' (forward), 5'-aacttcga cgaggtccacca-3' (reverse); GSTUM_00005271001 (D5GA F9), 5'-gtttgacacccgccgataa-3' (forward), 5'-aaggttcctgcaccc acaga-3' (reverse); GSTUM_00000555001 (D5GC43), 5'-gtt gaaaacgcacgcctctc-3' (forward), 5'-gccctcatcctcgacaacac-3' (reverse); GSTUM_00005237001 (D5GAC6), 5'-acctgtgcga ttctggtgct-3' (forward), 5'-atccgtaggctcoccaaaat-3' (reverse); GSTUM_00006427001 (D5GE86), 5'-gaagccaatctcggaggtga3' (forward), 5'-aaaacggcttccggtgtctt-3' (reverse); GSTUM_ 00001447001 (D5G5R4), 5'-gagctcctcggaaagcatca-3' (forward), 5'-ccaggaagaggggtttgtcc-3' (reverse); DQ223686.1 (Q1ACW3), 5'-gaaggctctccgctacgaca-3' (forward), 5'-accgca agccttgactttga-3' (reverse); AF054901, 5'-actagggatcgggc gatgtt-3' (forward), 5'-cagccttgcgaccatactcc-3' (reverse).

\footnotetext{
Abbreviations

2-DE: Two-dimensional gel electrophoresis; qPCR: Quantitative polymerase chain reaction; SSR: Simple sequence repeat; MS: Mass spectrometry; MALDITOF: Matrix-assisted laser desorption/ionization-Time-of-Flight; ESI: Electrospray ionization; $\mathrm{NAD}^{+}$or $\mathrm{NADP}^{+}$: Nicotinamide adenine dinucleotide or nicotinamide adenine dinucleotide phosphate; TCA: Tricarboxylic acid; ROS: Reactive oxygen species; ER: Endoplasmic reticulum; GTP: Guanosine triphosphate; CFU: Colony forming unit; CHAPS: 3 [(3-Cholamidopropyl)dimethylammonio]-propanesulfonic acid; DTT: Dithiothreitol; BSA: Bovine serum albumin; IEF: IsoElectric Focusing; SDS-PAGE: Sodium Dodecyl Sulfate PolyAcrylamide Gel Electrophoresis; IPG: Immobilized pH Gradient; IAA: lodoacetamide; Mr: Relative molecular mass; MW: Molecular weight.
}

\section{Competing interests}

The authors declare that they have no competing interests.

\section{Authors' contributions}

FV and VL carried out the proteins extraction and separation; EA performed MS analysis; AB designed MS experiments; MA designed image and statistical analysis and revised the manuscript; $R B$ and $A M$ revised the mycological aspects of the manuscript; AA drafted the manuscript. All authors read and approved the final manuscript.

\section{Author details}

${ }^{1}$ Department of Crop Plant Biology, University of Pisa, via Mariscoglio 34, 56124 Pisa, Italy. ${ }^{2}$ Biomolecular Mass Spectrometry Unit, San Raffaele Scientific Institute, Milan, Italy. ${ }^{3}$ Proteome Biochemistry Unit, San Raffaele Scientific Institute, Milan, Italy. ${ }^{4}$ Plant Protection Institute, Turin UOS, CNR, Viale Mattioli, 25, 10125 Turin, Italy.

Received: 17 April 2012 Accepted: 23 December 2012 Published: 1 February 2013

\section{References}

1. Splivallo R, Ottonello S, Mello A, Karlovsky P: Truffle volatiles: from chemical ecology to aroma biosynthesis. New Phytol 2011, 189:688-699.

2. Mello A, Murat C, Bonfante P: Truffles: much more than a prized and local fungal delicacy. FEMS Microbiol Lett 2006, 260:1-8.

3. Splivallo R, Valdez N, Kirchhoff N, Ona MC, Schmidt J-P, Feussner I, Karlovsky $P$ : Intraspecific genotypic variability determines concentrations of key truffle volatiles. New Phytol 2012, 194:823-835.

4. Martin F, Kohler A, Murat C, Balestrini R, Coutinho PM, Jaillon O, Montanini $B$, Morin E, Noel B, Percudani R, et al: Périgord black truffle genome uncovers evolutionary origins and mechanisms of symbiosis. Nature 2010, 464:1033-1038.

5. Stocchi V, Bonfante P, Nuti M: Biotechnology of ectomycorrhizae. New York: Plenum press; 1995.

6. Paolocci F, Rubini A, Riccioni C, Arcioni S: Reevaluation of the life cycle of Tuber magnatum. Appl Environ Microbiol 2006, 72:2390-2393.

7. Mouchès C, Duthil P, Bove JM, Valjalo J, Delmas J: Charactérisation des champignons supérieurs par électrophorés de leurs protéines. Mushr Sci 1978, 10:491-503.

8. Dupré C, Chevalier G, Branlard G: Charactèrisation des mycorhizes de differents Tuber par l'etude du polymorphisme enzymatique. In C.R. $1 r$ Coll. Natl. sur le technies de purification des proteines. Paris: DIPC-INPL public; 1984:465-467

9. Gandeboeuf D, Dupré C, Chevalier G: Differenciation des truffes europennees d'interet commercial par analyse des isoenzymes. Acta Botanica Gallica 1994, 141:455-463.

10. de Oliveira JM, de Graaff LH: Proteomics of industrial fungi: trends and insights for biotechnology. Appl Microbiol Biotechnol 2011, 89:225-237.

11. Jorge I, Navarro RM, Lenz C, Ariza S, Jorrin J: Variation in the holm oak leaf proteome at different plant developmental stages, between provenances and in response to drought stress. Proteomics 2006, 6:207-214.

12. Zeppa S, Guidi C, Zambonelli A, Potenza L, Vallorani L, Pierleoni R, Sacconi C, Stocchi V: Identification of putative genes involved in the development of Tuber borchii fruit body by mRNA differential display in agarose gel. Curr Genet 2002, 42:161-168.

13. Garnero L, Lazzari B, Mainieri D, Viotti A, Bonfante P: TMpcp: a Tuber magnatum gene which encodes a putative mitochondrial phosphate carrier. DNA Seq 2000, 10:407-410.

14. Weissbach H, Etienne F, Hoshi T, Heinemann SH, Lowther WT, Matthews B, St John G, Nathan C, Brot N: Peptide methionine sulfoxide reductase: structure, mechanism of action, and biological function. Arch Biochem Biophys 2002, 397:172-178.

15. Landaud S, Helinck S, Bonnarme P: Formation of volatile sulfur compounds and metabolism of methionine and other sulfur compounds in fermented food. Appl Microbiol Biotechnol 2008, 77:1191-1205.

16. Kersten PJ: Glyoxal oxidase of Phanerochaete chrysosporium : Its characterization and activation by lignin peroxidase. Proc Natl Acad Sci USA 1990, 87:2936-2940.

17. Whittaker MM, Kersten PJ, Cullen D, Whittaker JW: Identification of catalytic residues in glyoxal oxidase by targeted mutagenesis. J Biol Chem 1999, 274:36226-36232.

18. Jazdzewski BA, Tolman WB: Understanding the copper-phenoxyl radical array in galactose oxidase: contributions from synthetic modeling studies. Coord Chem Rev 2000, 200:633-685. 
19. Hamilton GA, Adolf PK, de Jersey J, DuBois GC, Dyrkacz GR, Libby RD: Trivalent copper, superoxide, and galactose oxidase. J Am Chem Soc 1978, 100:1899-1912.

20. Ceccaroli P, Saltarelli R, Guescini M, Polidori E, Buffalini M, Menotta M, Pierleoni R, Barbieri E, Stocchi V: Identification and characterization of the Tuber borchii D-mannitol dehydrogenase which defines a new subfamily within the polyol-specific medium chain dehydrogenases. Fungal Genet Biol 2007, 44:965-78

21. Ceccaroli P, Buffalini M, Saltarelli R, Barbieri E, Polidori E, Ottonello S, Kohler A, Tisserant E, Martin F, Stocchi V: Genomic profiling of carbohydrate metabolism in the ectomycorrhizal fungus Tuber melanosporum. New Phytol 2011, 189:751-764.

22. Abbà $S$, Balestrini $R$, Benedetto $A$, Rottensteiner $H$, De Lucas JR, Bonfante $P$ : The role of the glyoxylate cycle in the symbiotic fungus Tuber borchii: expression analysis and subcellular localization. Curr Genet 2007, 52:159-170,

23. Whittaker MM, Kersten PJ, Nakamura N, Sanders-Loehr J, Schweizer ES, Whittaker JW: Glyoxal oxidase from Phanerochaete chrysosporium is a new radical-copper oxidase. J Biol Chem 1996, 271(2):681-687.

24. Murat C, Vizzini A, Bonfante P, Mello A: Morphological and molecular typing of the below-ground fungal community in natural Tuber magnatum truffle-ground. FEMS Microbiol Lett 2005, 245:307-313.

25. Yang Q, Wang Y, Zhang J, Shi W, Qian C, Peng X: Identification of aluminum-responsive proteins in rice roots by proteomic approach: cysteine synthase as a key player in Al response. Proteomics 2007, 7:737-749.

26. Corti V, Cattaneo A, Bachi A, Rossi RE, Monasterolo G, Paolucci C, Burastero $\mathrm{SE}$, Alessio M: Identification of grass pollen allergene by $2 \mathrm{D}-$ electrophoresis and serological screening. Proteomics 2005, 5:729-736.

27. Fanucchi F, Alpi E, Olivieri S, Cannistraci CV, Bachi A, Alpi A, Alessio M: Acclimation increases freezing stress response of Arabidopsis thaliana at proteome level. Bioch Bioph Acta (BBA) - Proteins and Proteomics 2012, 6:813-825.

28. Shevchenko A, Wilm M, Vorm O, Mann M: Mass spectrometric sequencing of proteins silver-stained polyacrylamide gels. Anal Chem 1996, 68:850-858.

29. Chomczynski P, Sacchi N: The single-step method of RNA isolation by acid guanidinium thiocyanate-phenol-chloroform extraction: twentysomething years on. Nat Protoc 2006, 1:581-585.

30. Licausi F, Van Dongen JT, Giuntoli B, Novi G, Santaniello A, Geigenberger P, Perata P: HRE1 and HRE2, two hypoxia-inducible ethylene response factors, affect anaerobic responses in Arabidopsis thaliana. Plant J 2010, 62:302-315

doi:10.1186/1477-5956-11-7

Cite this article as: Vita et al:: Proteins from Tuber magnatum Pico fruiting bodies naturally grown in different areas of Italy. Proteome Science 2013 11:7.

\section{Submit your next manuscript to BioMed Central and take full advantage of:}

- Convenient online submission

- Thorough peer review

- No space constraints or color figure charges

- Immediate publication on acceptance

- Inclusion in PubMed, CAS, Scopus and Google Scholar

- Research which is freely available for redistribution

Submit your manuscript at www.biomedcentral.com/submit
Ciomed Central 